\title{
On the Agile Mindset of an Effective Team - An Industrial Opinion Survey
}

\author{
Jakub Miler \\ Gdansk University of Technology \\ Faculty of Electronics, Telecommunications \\ and Informatics \\ 11/12 Narutowicza St., 80-233, Gdansk, Poland \\ Email: jakub.miler@eti.pg.edu.pl
}

\author{
Paulina Gaida \\ Omida Finance Sp. z o.o. \\ Grunwaldzka 472B St., \\ 80-309 Gdańsk, Poland \\ Email: paulina.gaida@gmail.com
}

\begin{abstract}
In this paper we present the results of an opinion survey among 52 agile practitioners who evaluated the importance of 26 selected elements of the agile mindset to the effectiveness of an agile team. In total, we have identified 70 unique agile mindset elements based on 11 literature sources and 5 interviews with industry experts. 7 elements belonged to the "support for business goals" category, 20 to the "relationships within the team" category, 24 to the "individual features" category, and 19 to the "organization of work" category. Our survey shows the relative importance of the selected 26 agile mindset elements according to our respondents which is not fully consistent with the principles behind the Agile Manifesto.
\end{abstract}

\section{INTRODUCTION}

A gile Manifesto [1] together with the principles behind the Agile Manifesto [2] founded a set of driving values and key principles for the agile software development. Agile practitioners emphasize that effective performance of an agile team requires not only a given set of procedures, techniques and rituals, but, above all, a particular attitude, way of thinking and behavior of both the individuals and the entire team - a so called 'agile mindset' [3, 4].

Working in agile teams requires many non-technical and social competencies related to communication, organization, business, improvement and many more [5]. These are not the typical strong competencies among software engineers [6], which is why they require support of Scrum Masters, mentors and coaches to develop deep understanding of the fundamentals of Agile. Agile mindset, by addressing all of these competence areas and by suggesting important factors to the effective teamwork, supports practitioners in mastering Agile in their projects [4]. Altogether, developing the proper agile mindset contributes to the increasing success of agile software projects [7].

The principles behind the Agile Manifesto themselves [2] recommend such attitudes and behaviors as focus on customer satisfaction, openness to change, face-to-face communication, sustainable development, simplicity, selforganization and improvement by frequent reflection. The

This work was partially supported by the DS Funds of ETI Faculty, Gdansk University of Technology. agile methods such as Scrum [8], Kanban [9], SAFe [10] and other elaborate these principles further on, however the evolution of the IT industry since the Agile Manifesto calls for deeper and more current insight into the concept of 'being and working agile'. In our research, we assume the definition of 'an agile mindset' as a set of one's attitudes, behaviors and ways of thinking that enhance their and their team's effectiveness in working following the agile values and principles to the benefit of the customers.

This research aims at studying the elements of the agile mindset and their importance to the effectiveness of an agile team. We have formulated the following research questions: (RQ1) What agile mindset should the members of an agile team have? (RQ2) What is the importance of the particular agile mindset elements to the effectiveness of an agile team? (RQ3) What are the most important elements of the agile mindset to the effectiveness of an agile team?

The main contribution of this paper is the broad identification of the elements of agile mindset and the partial evaluation of their importance to the effectiveness of an agile team based on an industrial opinion survey. This extends the reviewed literature with deeper understanding of the concept of 'agile mindset' and the relative importance of its elements.

The paper is structured as follows. Section II presents our research method of identification, selection and evaluation of the agile mindset elements. Section III reports the results of the identification phase based on the literature review and the interviews with experts. Section IV presents the selection of the agile mindset elements for further evaluation. Section $\mathrm{V}$ reports the results of the survey together with the analysis of confounding variables and the comparison to the principles behind the Agile Manifesto. Section VI discusses the threats to the validity of this research, followed by the discussion in Section VII and conclusions in Section VIII.

\section{II.RESEARCH METHOD}

Our research comprised three steps: (1) identification of the elements of an agile mindset and their categorization, (2) selection of the agile mindset elements for evaluation, (3) evaluation of the relative importance of the selected agile mindset elements to the effectiveness of an agile team. 
The first step involved the review of current literature and the interviews with experts from industry. The literature review covered mainly grey literature (books, blogs, portals), as the scientific databases such as Scopus or Web of Science provided very few results. We have focused on Internet sources reporting on industrial practice or written by agile practitioners and published by renowned publishers or portals. In total, we analyzed 11 literature sources.

To identify the agile mindset elements more thoroughly, we have carried out 5 structured interviews with industry experts with 2 to 5 years of experience in agile teams. They mostly worked as developers and Scrum Masters with various agile methods. The characteristics of the interviewed experts are given in Table I. Experience is given in years.

TABLE I.

CHARACTERISTICS OF THE INTERVIEWED EXPERTS

\begin{tabular}{|l|l|c|c|}
\hline ID & \multicolumn{1}{|c|}{ Position } & Exp. & Methods \\
\hline A & developer & 3 & Scrum \\
\hline B & developer, tester & 2 & Kanban \\
\hline C & developer & 2 & Scrum \\
\hline D & Scrum Master, Agile Coach & 5 & Scrum, Kanban, XP \\
\hline E & Scrum Master & 3 & $\begin{array}{c}\text { Scrum, Kanban, } \\
\text { Scrumban }\end{array}$ \\
\hline
\end{tabular}

The interviews were carried out in late May - early June 2018 in a form of face to face meetings. Experts A to $\mathrm{C}$ were not provided the interview questions in advance, which resulted in limited answers. Thus, experts D and E were sent the questions before the interview, which allowed them to think over their answers and generally resulted in more original insight into the subject matter. We have followed the given interview guide:

I. Preliminary questions:

1. For how long have you been working in agile teams?

2. What methodology are you using in your projects (Scrum, Kanban, XP - Extreme Programming, others)?

3. What is your role in the team (developer, tester, Scrum Master, etc.)?

II. General questions about the philosophy of agility:

1. What is agility for you?

2. What does "agile mindset" mean for you?

III. Questions about agile mindset elements (at least 3 elements from each question):

1. Which beliefs do you think are necessary to have the agile mindset?

2. What are the most important values for a person with the agile mindset?

3. What principles should be followed by a person with the agile mindset?

IV. Questions about the importance of agile mindset elements (at least 5 elements from each question):

1. What are the most important attitudes, rules and behaviors at the interpersonal level in an agile team?
2. What are the most important attitudes, rules and behaviors in the work organization of an agile team?

3. What are the most important attitudes, rules and behaviors when dealing with customers in an agile team?

V. Questions about the impact of agile mindset on work efficiency:

1. What attitudes, behaviors and beliefs have the greatest impact on the efficiency of agile teams (name at least 5)?

2. Has your team worked inefficiently for reasons related to the agile mindset? What were these reasons?

3. Do you think it is necessary to have the agile mindset to work effectively in an agile team? Why?

Categorization of the identified agile mindset elements was done a posteriori based on keyword analysis in the results of the literature review. The same categorization was used for the interview results. The final list of identified agile mindset elements was elaborated by summing the sets of elements in the literature review results and interview results in each category, followed by merging the duplicates. We have noted the number of times each element was mentioned in the literature and the interviews (i.e. number of sources and number of experts, respectively, see Tables II and III).

The total number of identified agile mindset elements exceeded the capacity of a practical survey, so we had to select a subset of elements for further evaluation. As we aimed at one question per agile mindset element, we wanted to select no more than 30 agile mindset elements based on their frequency in sources (which is not importance). We have decided to include the elements found in at least 6 out of 11 literature sources or given by at least 2 out of 5 experts. These thresholds assume the majority of literature sources and some minimal agreement of the experts. Such thresholds favor the elements given by the experts, but this was our deliberate decision. Finally, such criteria resulted in 26 agile mindset elements selected for further evaluation. Other elements may be investigated in a separate study.

To evaluate the relative importance of the selected agile mindset elements to the effectiveness of an agile team, we have run a survey among agile practitioners in the IT industry. The survey was built on-line with Google Forms and distributed via e-mail, Facebook, forums etc. Respondents were asked to give their opinion on the degree to which a particular agile mindset element enhances the effectiveness of an agile team in the Likert-type 6 level scale of 0 to 5 , where 0 meant "no impact" and 5 meant "key impact". The answers were optional which accounted for the cases of respondents' indecision or insufficient knowledge. The survey was organized by agile mindset categories. Additionally, we asked about the respondents' experience and their role in agile teams. Although basic Likert scale is ordinal, we used the Likert-type interval scale with assigned values of 0 to 5 in the survey and the data analysis [11] 


\section{IDENTIFICATION OF AGILE MINDSET ELEMENTS}

\section{A. Literature review}

Using generic search engises such as Google, we have found the following literature on the topic of agile mindset:

1. "Agile Project Management: Managing for Success", a book by James A. Crowder and Shelli Friess [12],

2. "The Agile Enterprise: Building and Running Agile Organizations", a book by Mario E. Moreira [13],

3. "Being Agile: Your Roadmap to Successful Adoption of Agile", another book by Mario. E. Moreira [14],

4. "The Agile Mindset - Making Agile Processes Work", a book by Gil Broza [4],

5. "Five Agile Factors: Helping Self-management to Selfreflect", a research paper by Christoph J. Stettina and Werner Heijstek [15],

6. "Learning Agile: Understanding Scrum, XP, Lean and Kanban", a book by Andrew Stellman and Jennifer Greene [16],

7. "What Exactly is the Agile Mindset?", an on-line article by Susan McIntosh for InfoQ portal [17],

8. "What does it mean to have an agile mindset?", an online article by Leanne Howard for AgileConnection portal [18],

9. "It's All About the Mindset", an on-line article by Sayi Parvatam for Scrum Alliance portal [19],

10. "Fixed Mindset versus Agile Mindset", an on-line article by V. Godugu for Scrum Alliance portal [20],

11. "Agile Is Not a Process, It's a Mindset", an on-line article by Lisa Rich for AgileConnection portal [21].

In total, we identified 58 elements of agile mindset in the literature. Table III lists these elements grouped into categories with the indication of relevant sources. The identifier of each element combines the "L" prefix (standing for the literature), the category symbol and the consecutive number of the element in each category. The list is ordered by descending number of sources in each category.

We have identified four categories of the agile mindset elements: (1) support for business goals, (2) relationships within the team, (3) individual features, (4) organization of work. The first category, denoted by G symbol in Table III, focuses on the product value and relations with the customer. The second category, denoted by the $\mathrm{T}$ symbol, covers the issues of collaboration and relations within the agile team. The third category, denoted by the I symbol, tackles the behavior and attitude of an individual in an agile team. Finally, the fourth category, denoted by the $\mathrm{O}$ symbol, involves the aspects of methods, techniques and rules.

\section{B. Interviews with experts}

The 5 interviews with experts A to E provided 16, 18, 16, 17 , and 16 agile mindset elements, respectively. Repeating elements were merged. In total, we identified 39 unique agile mindset elements with the interviews. Table II lists these elements grouped into categories with the indication of relevant sources. The identifier of each element combines the "E" prefix (standing for the experts), the category symbol and the consecutive number of the element in each category. The categories and their symbol are the same as in the literature review. The list is ordered by descending number of interviews in each category.

\section{TABLE II.}

ELEMENTS OF THE AGILE MINDSET IDENTIFIED WITH THE INTERVIEWS

\begin{tabular}{|c|c|c|c|}
\hline ID & Element name & Source & $\mathbf{n}_{\mathbf{E}}$ \\
\hline E.G1 & $\begin{array}{l}\text { Cooperation with the customer based on } \\
\text { partnership }\end{array}$ & $\mathrm{B}, \mathrm{C}, \mathrm{D}$ & 3 \\
\hline E.G2 & $\begin{array}{l}\text { Attitude towards customer satisfaction and } \\
\text { needs }\end{array}$ & $\mathrm{B}, \mathrm{D}$ & 2 \\
\hline E.G3 & $\begin{array}{l}\text { Continuous delivery of a valuable product } \\
\text { in short intervals }\end{array}$ & A & 1 \\
\hline E.G4 & $\begin{array}{l}\text { No assumption that the customer is always } \\
\text { right }\end{array}$ & $\mathrm{A}$ & 1 \\
\hline E.T1 & Mutual trust & $\mathrm{A}, \mathrm{B}, \mathrm{C}, \mathrm{D}, \mathrm{E}$ & 5 \\
\hline E.T2 & Sincerity & $\mathrm{A}, \mathrm{B}, \mathrm{C}, \mathrm{E}$ & 4 \\
\hline E.T3 & Helping each other & $\mathrm{B}, \mathrm{C}, \mathrm{D}, \mathrm{E}$ & 4 \\
\hline E.T4 & Mutual listening & $\mathrm{A}, \mathrm{B}, \mathrm{C}$ & 3 \\
\hline E.T5 & Mutual respect & $\mathrm{A}, \mathrm{B}, \mathrm{D}$ & 3 \\
\hline E.T6 & Equality in the team & $\mathrm{B}, \mathrm{C}, \mathrm{D}$ & 3 \\
\hline E.T7 & Focus on achieving common goal & $\mathrm{A}, \mathrm{C}, \mathrm{E}$ & 3 \\
\hline E.T8 & $\begin{array}{l}\text { Searching for a solution to the problem } \\
\text { instead of finding the guilty }\end{array}$ & $\mathrm{A}, \mathrm{B}$ & 2 \\
\hline E.T9 & $\begin{array}{l}\text { Direct communication - face to face } \\
\text { conversations }\end{array}$ & $\mathrm{B}, \mathrm{D}$ & 2 \\
\hline E.T10 & Team responsibility & $\mathrm{C}, \mathrm{E}$ & 2 \\
\hline E.T11 & $\begin{array}{l}\text { Taking into account the opinions of other } \\
\text { people }\end{array}$ & $\mathrm{A}$ & 1 \\
\hline E.I1 & Openness to change & $\mathrm{A}, \mathrm{B}, \mathrm{C}, \mathrm{D}, \mathrm{E}$ & 5 \\
\hline E.I2 & Positive attitude & $\mathrm{A}, \mathrm{B}, \mathrm{E}$ & 3 \\
\hline E.I3 & Continuous improvement and learning & $\mathrm{B}, \mathrm{C}, \mathrm{E}$ & 3 \\
\hline E.I4 & Being motivated & $\mathrm{A}, \mathrm{B}$ & 2 \\
\hline E.I5 & Openness to criticism and feedback & A, D & 2 \\
\hline E.I6 & Openness to others & C, D & 2 \\
\hline E.I7 & $\begin{array}{l}\text { Willingness to constantly acquire } \\
\text { knowledge }\end{array}$ & $\mathrm{B}$ & 1 \\
\hline E.I8 & Pragmatism & $\mathrm{B}$ & 1 \\
\hline E.I9 & Individual initiative & $\mathrm{B}$ & 1 \\
\hline E.I10 & Courage & $\mathrm{D}$ & 1 \\
\hline E.I11 & Commitment & $\mathrm{D}$ & 1 \\
\hline E.I12 & Creativity, innovation & $\mathrm{D}$ & 1 \\
\hline E.I13 & Being a visionary & $\mathrm{D}$ & 1 \\
\hline E.I14 & Understanding the need for change & $\mathrm{E}$ & 1 \\
\hline E.I15 & Responsibility & $\mathrm{E}$ & 1 \\
\hline E.I16 & $\begin{array}{l}\text { Understanding the significance of } \\
\text { retrospectives }\end{array}$ & $\mathrm{E}$ & 1 \\
\hline E.O1 & Self-organization & $\mathrm{A}, \mathrm{C}, \mathrm{D}, \mathrm{E}$ & 4 \\
\hline E.O2 & $\begin{array}{l}\text { Finishing the current task before taking the } \\
\text { next one }\end{array}$ & $\mathrm{A}, \mathrm{C}, \mathrm{E}$ & 3 \\
\hline E.O3 & $\begin{array}{l}\text { Asking questions in case of insufficient } \\
\text { knowledge }\end{array}$ & $\mathrm{B}, \mathrm{C}, \mathrm{D}$ & 3 \\
\hline E.O4 & Maintaining a steady pace of work & $\mathrm{A}, \mathrm{E}$ & 2 \\
\hline E.O5 & $\begin{array}{l}\text { Transparency in decision-making and } \\
\text { actions }\end{array}$ & $\mathrm{C}, \mathrm{E}$ & 2 \\
\hline E.06 & Sharing knowledge and results & $\mathrm{C}$ & 1 \\
\hline E.O7 & Focus on the tasks performed & $\mathrm{D}$ & 1 \\
\hline E.O8 & Focus on cross-functional teams & $\mathrm{E}$ & 1 \\
\hline
\end{tabular}


TABLE III.

ELEMENTS OF THE AGILE MINDSET IDENTIFIED IN THE LITERATURE

\begin{tabular}{|c|c|c|c|}
\hline ID & Element name & Source & $\mathbf{n}_{\mathbf{L}}$ \\
\hline L.G1 & Continuous delivery of a valuable product in short intervals & [12], [13], [14], [4], [16], [17], [19] & 7 \\
\hline L.G2 & Attitude towards customer satisfaction and needs & [12], [13], [14], [16], [18] & 5 \\
\hline L.G3 & Belief that a working product is the basic measure of progress & [12], [13], [14] & 3 \\
\hline L.G4 & Continuous cooperation with the customer & [13], [14], [4] & 3 \\
\hline L.G5 & Accurate knowledge of who the customer is and what are their needs & {$[14]$} & 1 \\
\hline L.G6 & Cooperation with the customer based on partnership & [16] & 1 \\
\hline L.T1 & Mutual trust & [12], [13], [14], [4], [15], [16], [19], [20] & 8 \\
\hline L.T2 & Direct communication - face to face conversations & [12], [13], [14], [4], [15], [16], [19] & 7 \\
\hline L.T3 & Focus on achieving common goal & [12], [13], [14], [15], [18], [19] & 6 \\
\hline L.T4 & Mutual respect & [14], [4], [15], [17], [19] & 5 \\
\hline L.T5 & Helping each other & [12], [14], [15] & 3 \\
\hline L.T6 & Taking into account the opinions of other people & [13], [15] & 2 \\
\hline L.T7 & Respecting the experience and skills in all team members & {$[13],[14]$} & 2 \\
\hline L.T8 & Listening to the opinions of other people & {$[14],[15]$} & 2 \\
\hline L.T9 & Team responsibility & {$[14],[16]$} & 2 \\
\hline L.T10 & Treating team members as people, not a resource & {$[14],[20]$} & 2 \\
\hline L.T11 & Openness to others & [14], [20] & 2 \\
\hline L.T12 & Sincerity & [14], [21] & 2 \\
\hline L.T13 & A relaxed atmosphere & [19], [20] & 2 \\
\hline L.T14 & Equality in the team & [14] & 1 \\
\hline L.T15 & Sense of security & [4] & 1 \\
\hline L.T16 & Focus on people instead of on processes & [16] & 1 \\
\hline L.T17 & Not blaming each other & [16] & 1 \\
\hline L.T18 & Not covering up the failures & [18] & 1 \\
\hline L.T19 & Searching for a solution to the problem instead of finding the guilty & [18] & 1 \\
\hline L.I1 & Continuous improvement and learning & [12], [13], [14], [4], [15], [16], [17], [18], [20] & 9 \\
\hline L.I2 & Openness to change & [12], [13], [14], [4], [16], [17], [18], [20] & 8 \\
\hline L.I3 & Being motivated & [12], [13], [14], [16], [19], [20] & 6 \\
\hline L.I4 & Treating failure as an opportunity to learn, learning from mistakes & [4], [16], [17], [20], [21] & 5 \\
\hline L.I5 & Creativity, innovation & [13], [18], [19] & 3 \\
\hline L.I6 & Ability to accept failure and deal with it & [17], [18], [21] & 3 \\
\hline L.I7 & Taking risks & [4], [17] & 2 \\
\hline L.I8 & Willingness to constantly acquire knowledge & [15], [18] & 2 \\
\hline L.I9 & Positive attitude & [18], [19] & 2 \\
\hline L.I10 & Assertiveness & [14] & 1 \\
\hline L.I11 & Focus on the task being performed & [4] & 1 \\
\hline L.I12 & A sense of pride in the job & [17] & 1 \\
\hline L.I13 & Not giving up & [18] & 1 \\
\hline L.I14 & Inquisitiveness & [18] & 1 \\
\hline L.I15 & Pragmatism & [18] & 1 \\
\hline L.O1 & Self-organization & [12], [13], [14], [4], [15], [16], [19] & 7 \\
\hline L.O2 & Ability to collaborate & [12], [13], [14], [4], [16], [17], [20] & 7 \\
\hline L.O3 & Maintaining a steady pace of work & [12], [13], [14], [4], [16], [20] & 6 \\
\hline L.O4 & Sharing knowledge and results & [12], [13], [14], [18], [19], [20] & 6 \\
\hline L.O5 & Simplicity and maximization of unnecessary work, simplifying tasks & [12], [13], [14], [4], [16] & 5 \\
\hline L.O6 & Transparency in decision-making and actions & [12], [14], [4], [20], [21] & 5 \\
\hline L.O7 & Ability to make decisions together & [12], [13], [14], [15] & 4 \\
\hline L.O8 & Interdisciplinarity & [12], [13], [14] & 3 \\
\hline L.O9 & Attitude towards working in short iterations with small increments & {$[14],[16]$} & 2 \\
\hline L.O10 & Applying retrospectives to identify areas for improvement & {$[14],[16]$} & 2 \\
\hline L.O11 & Understanding the purpose and vision of the task before taking it & {$[4],[15]$} & 2 \\
\hline L.O12 & Focus on cross-functional teams & [15] & 1 \\
\hline L.O13 & Expressing feedback on the work of other people & [15] & 1 \\
\hline L.O14 & Estimating the results for a given timeframe & [16] & 1 \\
\hline L.O15 & Determining possible tasks instead of looking for excuses & [18] & 1 \\
\hline L.O16 & Asking questions in case of insufficient knowledge & [20] & 1 \\
\hline L.O17 & Focus on one task instead of many at once & [21] & 1 \\
\hline L.O18 & Finishing the current task before taking the next one & [21] & 1 \\
\hline
\end{tabular}




\section{Final list merged from literature and interviews}

Finally, we merged the lists of agile mindset elements identified from literature and with the interviews. The resulting list of unique agile mindset elements comprises 70 entries, which exceeds the limitations of this paper. However, all identified agile mindset elements were already shown in Table II and Table III. Table IV shows the number of agile mindset elements in each category identified in the literature and the interviews as well as the number of unique elements in our final list.

TABLE IV.

NUMBER OF IDENTIFIED AGILE MINDSET ELEMENTS

\begin{tabular}{|l|l|l|l|}
\hline \multicolumn{1}{|c|}{ Category } & Literature & Interviews & Unique \\
\hline Support for business goals & 6 & 4 & 7 \\
\hline Relationships within the team & 19 & 11 & 20 \\
\hline Individual features & 15 & 16 & 24 \\
\hline Organization of work & 18 & 8 & 19 \\
\hline Total & 58 & 39 & 70 \\
\hline
\end{tabular}

\section{SELECTION OF AGILE MINDSET ELEMENTS}

Based on the criteria presented in section II, we have selected 26 elements of agile mindset out of 70 for further evaluation with the opinion survey. We selected 3 elements out of 7 in the "support for business goals" category, 10 elements out of 20 in the "relationships within the team" category, 6 elements out of 24 in the "individual features" category, and 7 elements out of 19 in the "organization of work" category. We could observe that 13 elements in the "individual features" category as well as 8 elements in the "organization of work" category were mentioned only in one source, be it literature or interview.

The list of elements selected for the survey is shown in Table V. $\mathrm{n}_{\mathrm{L}}$ column presents the number of literature sources, while $\mathrm{n}_{\mathrm{E}}$ column presents the number of experts mentioning each element. The final unique agile mindset elements were given new identifiers prefixed with the category symbol only, as described in section III. The identifiers of the merged elements from the literature (see Table III) and the interviews (see Table II) are given in columns $\mathrm{ID}_{\mathrm{L}}$ and $\mathrm{ID}_{\mathrm{E}}$, respectively.

TABLE V.

ELEMENTS OF THE AGILE MINDSET SELECTED FOR THE SURVEY

\begin{tabular}{|l|l|l|l|l|l|}
\hline ID & \multicolumn{1}{|c|}{ Element name } & $\mathbf{n}_{\mathbf{L}}$ & $\mathbf{n}_{\mathbf{E}}$ & \multicolumn{1}{|c|}{$\mathbf{I D}_{\mathbf{L}}$} & $\mathbf{I D}_{\mathbf{E}}$ \\
\hline G1 & $\begin{array}{l}\text { Continuous delivery of a valuable } \\
\text { product in short intervals }\end{array}$ & 7 & 1 & L.G1 & E.G3 \\
\hline G2 & $\begin{array}{l}\text { Cooperation with the customer } \\
\text { based on partnership }\end{array}$ & 1 & 3 & L.G6 & E.G1 \\
\hline G3 & $\begin{array}{l}\text { Attitude towards customer } \\
\text { satisfaction and needs }\end{array}$ & 5 & 2 & L.G2 & E.G2 \\
\hline T1 & Mutual trust & 8 & 5 & L.T1 & E.T1 \\
\hline T2 & $\begin{array}{l}\text { Direct communication - face to } \\
\text { face conversations }\end{array}$ & 7 & 2 & L.T2 & E.T9 \\
\hline T3 & Focus on achieving common goal & 6 & 3 & L.T3 & E.T7 \\
\hline T4 & Helping each other & 3 & 4 & L.T5 & E.T3 \\
\hline T5 & Sincerity & 2 & 4 & L.T12 & E.T2 \\
\hline
\end{tabular}

\begin{tabular}{|l|l|l|l|l|l|}
\hline T6 & Mutual respect & 5 & 3 & L.T4 & E.T5 \\
\hline T7 & Mutual listening & 0 & 3 & - & E.T4 \\
\hline T8 & Equality in the team & 1 & 3 & L.T14 & E.T6 \\
\hline T9 & $\begin{array}{l}\text { Searching for a solution to the } \\
\text { problem instead of finding the } \\
\text { guilty }\end{array}$ & 1 & 2 & L.T19 & E.T8 \\
\hline T10 & Team responsibility & 2 & 2 & L.T9 & E.T10 \\
\hline I1 & $\begin{array}{l}\text { Continuous improvement and } \\
\text { learning }\end{array}$ & 9 & 3 & L.I1 & E.I3 \\
\hline I2 & Openness to change & 8 & 5 & L.I2 & E.I1 \\
\hline I3 & Being motivated & 6 & 2 & L.I3 & E.I4 \\
\hline I4 & Positive attitude & 2 & 3 & L.I9 & E.I2 \\
\hline I5 & Openness to criticism and feedback & 0 & 2 & - & E.I5 \\
\hline I6 & Openness to others & 0 & 2 & - & E.I6 \\
\hline O1 & Self-organization & 7 & 4 & L.O1 & E.O1 \\
\hline O2 & Maintaining a steady pace of work & 6 & 2 & L.O3 & E.O4 \\
\hline O3 & Ability to collaborate & 7 & 0 & L.O2 & - \\
\hline O4 & Sharing knowledge and results & 6 & 1 & L.O4 & E.O6 \\
\hline O5 & $\begin{array}{l}\text { Asking questions in case of } \\
\text { insufficient knowledge }\end{array}$ & 1 & 3 & L.O16 & E.O3 \\
\hline O6 & $\begin{array}{l}\text { Finishing the current task before } \\
\text { taking the next one }\end{array}$ & 1 & 3 & L.O18 & E.O2 \\
\hline O7 & $\begin{array}{l}\text { Transparency in decision-making } \\
\text { and actions }\end{array}$ & 5 & 2 & L.O6 & E.O5 \\
\hline
\end{tabular}

\section{EVALUATION OF AGILE MINDSET ELEMENTS}

\section{A. Characteristics of respondents}

The evaluation survey was carried out in late June and early July 2018. The questionnaire comprised 5 sections: an introductory section and 4 sections with the agile mindset elements to evaluate grouped into their categories. In total, 52 respondents took part in the survey. Table VI shows the distribution of the respondents' experience with agile. Most of the respondents $(52 \%)$ had at least 2 years of experience.

TABLE VI.

DISTRIBUTION OF THE EXPERIENCE OF SURVEY RESPONDENTS

\begin{tabular}{|l|c|}
\hline Experience years & $\mathbf{n}$ \\
\hline$<1$ & 7 \\
\hline $1-2$ & 18 \\
\hline $2-3$ & 13 \\
\hline $3-5$ & 7 \\
\hline$>5$ & 7 \\
\hline
\end{tabular}

Table VII shows the distribution of respondents' roles in agile teams. Most of them worked as developers (about $60 \%$ ), while others worked mostly as Scrum Masters.

TABLE VII.

DISTRIBUTION OF THE ROLES OF SURVEY RESPONDENTS

\begin{tabular}{|l|c|}
\hline \multicolumn{1}{|c|}{ Role } & n \\
\hline Developer & 31 \\
\hline Scrum Master & 13 \\
\hline Tester & 3 \\
\hline Product Owner & 2 \\
\hline Agile Coach & 1 \\
\hline Analyst & 1 \\
\hline UX Designer & 1 \\
\hline
\end{tabular}




\section{B. Evaluation of agile mindset elements and categories}

Table VIII presents the evaluation of the importance of selected agile mindset elements to the effectiveness of an agile team according to the respondents' opinion. E shows the mean evaluation of an agile mindset element in the Likert-type scale of 0 to 5 with standard deviation; $\mathrm{n}$ gives the sample size. The sample size slightly differs for some elements due to the option to skip an element in the survey. The elements are ordered by their decreasing evaluation.

TABLE VIII.

EVALUATION OF THE IMPORTANCE OF AGILE MINDSET ELEMENTS TO THE TEAM EFFECTIVENESS

\begin{tabular}{|c|c|c|c|c|}
\hline No. & ID & Element name & $\mathbf{E}$ & $\mathbf{n}$ \\
\hline 1 & T9 & $\begin{array}{l}\text { Searching for a solution to the } \\
\text { problem instead of finding the guilty }\end{array}$ & $4.44(0.79)$ & 52 \\
\hline 2 & $\mathrm{I} 3$ & Being motivated & $4.44(0.69)$ & 52 \\
\hline 3 & $\mathrm{~T} 4$ & Helping each other & $4.40(0.63)$ & 52 \\
\hline 4 & $\mathrm{~T} 7$ & Mutual listening & $4.37(0.71)$ & 51 \\
\hline 5 & T3 & Focus on achieving common goal & $4.29(0.77)$ & 52 \\
\hline 6 & I5 & Openness to criticism and feedback & $4.23(0.82)$ & 52 \\
\hline 7 & $\mathrm{O} 4$ & Sharing knowledge and results & $4.21(0.86)$ & 52 \\
\hline 8 & T6 & Mutual respect & $4.11(0.91)$ & 52 \\
\hline 9 & $\mathrm{~T} 1$ & Mutual trust & $4.10(0.96)$ & 51 \\
\hline 10 & T5 & Sincerity & $4.09(0.97)$ & 52 \\
\hline 11 & I1 & $\begin{array}{l}\text { Continuous improvement and } \\
\text { learning }\end{array}$ & $4.08(1.00)$ & 52 \\
\hline 12 & O7 & $\begin{array}{l}\text { Transparency in decision-making } \\
\text { and actions }\end{array}$ & $4.08(1.03)$ & 52 \\
\hline 13 & $\mathrm{O} 1$ & Self-organization & $4.04(0.88)$ & 52 \\
\hline 14 & $\mathrm{I} 2$ & Openness to change & $4.00(1.02)$ & 52 \\
\hline 15 & G1 & $\begin{array}{l}\text { Continuous delivery of a valuable } \\
\text { product in short intervals }\end{array}$ & $3.96(1.04)$ & 52 \\
\hline 16 & G3 & $\begin{array}{l}\text { Attitude towards customer } \\
\text { satisfaction and needs }\end{array}$ & $3.92(0.83)$ & 52 \\
\hline 17 & G2 & $\begin{array}{l}\text { Cooperation with the customer based } \\
\text { on partnership }\end{array}$ & $3.88(0.97)$ & 52 \\
\hline 18 & I6 & Openness to others & $3.88(0.97)$ & 52 \\
\hline 19 & O6 & $\begin{array}{l}\text { Finishing the current task before } \\
\text { taking the next one }\end{array}$ & $3.86(1.06)$ & 52 \\
\hline 20 & I4 & Positive attitude & $3.84(0.77)$ & 52 \\
\hline 21 & O3 & Ability to collaborate & $3.81(0.90)$ & 52 \\
\hline 22 & O5 & $\begin{array}{l}\text { Asking questions in case of } \\
\text { insufficient knowledge }\end{array}$ & $3.74(1.06)$ & 51 \\
\hline 23 & $\mathrm{~T} 2$ & $\begin{array}{l}\text { Direct communication - face to face } \\
\text { conversations }\end{array}$ & $3.69(1.26)$ & 52 \\
\hline 24 & $\mathrm{~T} 8$ & Equality in the team & $3.42(1.28)$ & 52 \\
\hline 25 & $\mathrm{~T} 10$ & Team responsibility & $3.23(1.31)$ & 52 \\
\hline 26 & $\mathrm{O} 2$ & Maintaining a steady pace of work & $3.04(1.34)$ & 52 \\
\hline
\end{tabular}

It can be seen that the top evaluated elements reached the evaluation of about 4.5 out of 5. 14 out of 26 elements reached the evaluation of 4.0 and above. They can be considered the recommended agile mindset elements in our survey. The lowest evaluated elements obtained the score of less than 3.5. However it should be noted that the standard deviation of the evaluations of the last 4 elements is the highest in all our study (about 1.3). Other elements were evaluated with the standard deviation of 0.69 to 1.06 .
We have also calculated the mean evaluation of all agile mindset elements in particular categories which is presented in Table IX. It can be observed that "individual features" are evaluated as the most important category. Next is "relationships within the team", followed by "support for business goal". "Organization of work" scored the lowest mean evaluation of all categories.

TABLE IX.

Mean eValuation OF THE AgILE MindSet CATEGories

\begin{tabular}{|l|l|l|}
\hline \multicolumn{1}{|c|}{ Category } & \multicolumn{1}{c|}{ E } & n \\
\hline Support for business goals & $3.92(0.95)$ & 156 \\
\hline Relationships within the team & $4.02(1.07)$ & 518 \\
\hline Individual features & $4.08(0.91)$ & 312 \\
\hline Organization of work & $3.83(1.09)$ & 363 \\
\hline
\end{tabular}

\section{Analysis of confounding variables}

We have analyzed the respondents' experience and role as confounding variables in the evaluations of agile mindset elements. The results are presented in Table X and Table XI.

TABLE $\mathrm{X}$.

EVALUATION OF AGILE MINDSET ELEMENTS BY EXPERIENCE

\begin{tabular}{|c|c|c|c|c|}
\hline ID & Element name & $\mathbf{E}_{\text {exp }<2}$ & $E_{\text {exp }>=2}$ & $\mathbf{p}$ \\
\hline G1 & $\begin{array}{l}\text { Continuous delivery of a valuable } \\
\text { product in short intervals }\end{array}$ & 4.08 & 3.82 & 0.362 \\
\hline G2 & $\begin{array}{l}\text { Cooperation with the customer based } \\
\text { on partnership }\end{array}$ & 3.88 & 3.93 & 0.870 \\
\hline G3 & $\begin{array}{l}\text { Attitude towards customer satisfaction } \\
\text { and needs }\end{array}$ & 3.88 & 3.85 & 0.914 \\
\hline T1 & Mutual trust & 4.20 & 4.00 & 0.465 \\
\hline $\mathrm{T} 2$ & $\begin{array}{l}\text { Direct communication - face to face } \\
\text { conversations }\end{array}$ & 3.76 & 3.67 & 0.795 \\
\hline T3 & Focus on achieving common goal & 4.40 & 4.19 & 0.323 \\
\hline $\mathrm{T} 4$ & Helping each other & 4.44 & 4.37 & 0.697 \\
\hline $\mathrm{T} 5$ & Sincerity & 4.28 & 3.93 & 0.194 \\
\hline T6 & Mutual respect & 4.12 & 4.11 & 0.973 \\
\hline $\mathrm{T} 7$ & Mutual listening & 4.32 & 4.42 & 0.614 \\
\hline T8 & Equality in the team & 3.48 & 3.37 & 0.763 \\
\hline T9 & $\begin{array}{l}\text { Searching for a solution to the problem } \\
\text { instead of finding the guilty }\end{array}$ & 4.60 & 4.30 & 0.175 \\
\hline T10 & Team responsibility & 2.96 & 3.48 & 0.158 \\
\hline I1 & Continuous improvement and learning & 4.12 & 4.04 & 0.770 \\
\hline $\mathrm{I} 2$ & Openness to change & 3.96 & 4.04 & 0.790 \\
\hline $\mathrm{I} 3$ & Being motivated & 4.56 & 4.33 & 0.246 \\
\hline I4 & Positive attitude & 4.04 & 4.67 & 0.083 \\
\hline I5 & Openness to criticism and feedback & 4.36 & 4.11 & 0.285 \\
\hline I6 & Openness to others & 4.24 & 3.56 & 0.018 \\
\hline $\mathrm{O} 1$ & Self-organization & 4.28 & 3.82 & 0.057 \\
\hline $\mathrm{O} 2$ & Maintaining a steady pace of work & 3.00 & 3.07 & 0.393 \\
\hline $\mathrm{O} 3$ & Ability to collaborate & 4.00 & 3.63 & 0.143 \\
\hline $\mathrm{O} 4$ & Sharing knowledge and results & 4.32 & 4.11 & 0.393 \\
\hline $\mathrm{O} 5$ & $\begin{array}{l}\text { Asking questions in case of } \\
\text { insufficient knowledge }\end{array}$ & 3.96 & 3.56 & 0.184 \\
\hline O6 & $\begin{array}{l}\text { Finishing the current task before } \\
\text { taking the next one }\end{array}$ & 3.92 & 3.93 & 0.981 \\
\hline $\mathrm{O} 7$ & $\begin{array}{l}\text { Transparency in decision-making and } \\
\text { actions }\end{array}$ & 3.96 & 4.19 & 0.443 \\
\hline
\end{tabular}


We have used the t-Student test for independent pairs to analyze the differences in mean evaluations depending on experience and role. Treating our data as numerical, this test is suitable for such analysis [11]. We assumed equal variances of the grouped samples and the confidence level of $95 \%(\alpha=0.05)$.

For the experience test we divided our sample into two groups: less than 2 years of experience and 2 or more years of experience (group sizes were 25 and 27, respectively, which satisfies the prerequisites to the selected test). The mean evaluations are given in Table $X$ in the $E_{\exp <2}$ and $E_{\text {exp }>=2}$ columns, respectively, followed by the $p$-value of the t-Student test.

For the role test we divided our sample into two groups: developers and non-developers (group sizes were 31 and 21, respectively). Other divisions were not possible due to insufficient number of samples for the prerequisites of the selected test. The mean evaluations are given in Table XI in the $E_{\text {dev }}$ and $E_{\text {ndev }}$ columns, respectively, followed by the p-value of the t-Student test.

TABLE XI.

EVALUATION OF AGILE MINDSET ELEMENTS BY ROLE

\begin{tabular}{|c|c|c|c|c|}
\hline ID & Element name & $\mathbf{E}_{\mathrm{dev}}$ & $\mathbf{E}_{\text {ndev }}$ & $\mathbf{p}$ \\
\hline G1 & $\begin{array}{l}\text { Continuous delivery of a valuable } \\
\text { product in short intervals }\end{array}$ & 3.98 & 3.91 & 0.832 \\
\hline $\mathrm{G} 2$ & $\begin{array}{l}\text { Cooperation with the customer based } \\
\text { on partnership }\end{array}$ & 3.87 & 3.95 & 0.775 \\
\hline G3 & $\begin{array}{l}\text { Attitude towards customer satisfaction } \\
\text { and needs }\end{array}$ & 3.87 & 3.86 & 0.959 \\
\hline $\mathrm{T} 1$ & Mutual trust & 4.00 & 4.25 & 0.371 \\
\hline $\mathrm{T} 2$ & $\begin{array}{l}\text { Direct communication - face to face } \\
\text { conversations }\end{array}$ & 3.39 & 4.14 & 0.035 \\
\hline T3 & Focus on achieving common goal & 4.36 & 4.19 & 0.459 \\
\hline $\mathrm{T} 4$ & Helping each other & 4.42 & 4.38 & 0.833 \\
\hline T5 & Sincerity & 4.03 & 4.19 & 0.571 \\
\hline T6 & Mutual respect & 4.19 & 4.00 & 0.463 \\
\hline $\mathrm{T} 7$ & Mutual listening & 4.47 & 4.24 & 0.269 \\
\hline $\mathrm{T} 8$ & Equality in the team & 3.48 & 3.29 & 0.595 \\
\hline T9 & $\begin{array}{l}\text { Searching for a solution to the problem } \\
\text { instead of finding the guilty }\end{array}$ & 4.52 & 4.33 & 0.426 \\
\hline $\mathrm{T} 10$ & Team responsibility & 3.19 & 3.29 & 0.808 \\
\hline I1 & Continuous improvement and learning & 3.94 & 4.29 & 0.222 \\
\hline $\mathrm{I} 2$ & Openness to change & 3.87 & 4.19 & 0.276 \\
\hline $\mathrm{I} 3$ & Being motivated & 4.52 & 4.33 & 0.359 \\
\hline $\mathrm{I} 4$ & Positive attitude & 3.84 & 3.86 & 0.934 \\
\hline I5 & Openness to criticism and feedback & 4.32 & 4.10 & 0.338 \\
\hline I6 & Openness to others & 3.94 & 3.81 & 0.655 \\
\hline $\mathrm{O} 1$ & Self-organization & 4.07 & 4.00 & 0.799 \\
\hline $\mathrm{O} 2$ & Maintaining a steady pace of work & 2.90 & 3.24 & 0.388 \\
\hline $\mathrm{O} 3$ & Ability to collaborate & 3.71 & 3.95 & 0.350 \\
\hline $\mathrm{O} 4$ & Sharing knowledge and results & 4.19 & 4.24 & 0.858 \\
\hline $\mathrm{O} 5$ & $\begin{array}{l}\text { Asking questions in case of } \\
\text { insufficient knowledge }\end{array}$ & 3.83 & 3.62 & 0.489 \\
\hline O6 & $\begin{array}{l}\text { Finishing the current task before } \\
\text { taking the next one }\end{array}$ & 3.65 & 4.19 & 0.070 \\
\hline O7 & $\begin{array}{l}\text { Transparency in decision-making and } \\
\text { actions }\end{array}$ & 4.10 & 4.05 & 0.870 \\
\hline
\end{tabular}

Both tests showed that the impact of both experience and role on nearly all of the evaluations could not be considered statistically significant with the assumed confidence level of $95 \%$ and sample size of 52 . However, two agile mindset elements stood out. The evaluation of I6 element "Openness to others" exhibited statistically significant difference in the evaluation depending on respondents' experience $(\mathrm{p}<\alpha$ in Table X). It was evaluated much higher (4.24 compared to $3.56)$ by the respondents with less than 2 years of experience. The evaluation of T2 element "Direct communication - face to face conversations" exhibited statistically significant difference in the evaluation depending on respondents' role $(\mathrm{p}<\alpha$ in Table XI). It was evaluated much lower (3.39 compared to 4.14 ) by the developers.

\section{Comparison to the principles behind Agile Manifesto}

We have mapped the elements of agile mindset in our study to the 12 principles behind the Agile Manifesto [2] and analyzed the evaluation and relative position of the agile mindset elements that map directly onto these principles. The results are shown in Table XII. P\# column shows the Agile principle number.

TABLE XII.

MAPPING OF AGILE MINDSET ELEMENTS ON AGILE PRINCIPLES

\begin{tabular}{|l|l|l|l|l|}
\hline No. & ID & \multicolumn{1}{|c|}{ Element name } & E & P\# \\
\hline 2 & I3 & Being motivated & $4.44(0.69)$ & 5 \\
\hline 9 & T1 & Mutual trust & $4.10(0.96)$ & 5 \\
\hline 11 & I1 & $\begin{array}{l}\text { Continuous improvement and } \\
\text { learning }\end{array}$ & $4.08(1.00)$ & 12 \\
\hline 13 & O1 & Self-organization & $4.04(0.88)$ & 11 \\
\hline 14 & I2 & Openness to change & $4.00(1.02)$ & 2 \\
\hline 15 & G1 & $\begin{array}{l}\text { Continuous delivery of a valuable } \\
\text { product in short intervals }\end{array}$ & $3.96(1.04)$ & 1, \\
\hline 16 & G3 & $\begin{array}{l}\text { Attitude towards customer } \\
\text { satisfaction and needs }\end{array}$ & $3.92(0.83)$ & 1 \\
\hline 17 & G2 & $\begin{array}{l}\text { Cooperation with the customer based } \\
\text { on partnership }\end{array}$ & $3.88(0.97)$ & 4 \\
\hline 23 & T2 & $\begin{array}{l}\text { Direct communication - face to face } \\
\text { conversations }\end{array}$ & $3.69(1.26)$ & 6 \\
\hline 26 & O2 & Maintaining a steady pace of work & $3.04(1.34)$ & 8 \\
\hline
\end{tabular}

It can be seen that only the I3 agile mindset element mapped to the $5^{\text {th }}$ Agile principle was evaluated very high (4.44, position 2). Elements mapped to most of the Agile principles were evaluated in the middle range (4.10 to 3.88 , positions 9 to 17). However, the elements $\mathrm{T} 2$ and $\mathrm{O} 2$ mapped to $6^{\text {th }}$ and $8^{\text {th }}$ principle respectively were evaluated very low (3.69 and 3.04, position 23 and 26 (last)). Remaining 2 Agile principles mapped to the agile mindset elements that were excluded from the survey.

\section{THREATS TO VALIDITY}

\section{A. Threats to construct and internal validity}

We have identified and reduced the following threats to the construct and internal validity of this research related to 
the interviews and the survey: (a) interview moderator's bias and influence on experts, (b) misinterpretation of the interview outputs, (c) learning and tiring of the survey respondents, (d) forced answers to the survey.

We have controlled the interview moderator's bias and their influence on experts with the structure of the interview. Each interview followed the same protocol (Section II). To minimize misinterpretations, the interviews were recorded, transcribed and thoroughly analyzed while relistening to the recordings, if necessary. The results of each interview have been coded separately and only then merged together.

The survey questions were not randomized to minimize the impact of learning and tiring of the respondents due to the limitation of the Google Forms tool. However, the survey was conveniently divided into 5 sections and contained only 26 evaluation questions. The survey also allowed the respondents to skip the evaluation of a particular agile mindset element when unsure.

\section{B. Threats to external validity}

We have identified the following threats to the external validity of the interviews and the survey: (a) low number of interviewed experts and survey respondents, (b) insufficient experience of interview experts and survey respondents, (c) interview experts and survey respondents as a convenience sample, (d) interview experts and survey respondents sample limited to Polish IT industry.

We have interviewed 5 experts from the industry. The interviewed experts had 2 to 5 years of experience in Agile. We aimed at covering various roles in an agile team and experiences with various agile methods. We engaged 2 Scrum Masters with broad experience (see Table I) Altogether, the input from experts supplemented the list of 58 agile mindset elements from the literature by 22 new elements $(38 \%)$, which can be considered a substantial contribution (see Table IV).

We have collected data from 52 respondents in the survey, which definitely exceeded the typical threshold sample size of 30 for the choice of the statistical tests [11]. 52\% of the respondents had at least 2 years of experience. $13.5 \%$ of the respondents had more than 5 years of experience (see Table VI). The respondents represented various roles in the agile team, which covered diverse points of view (see Table VII). Moreover, we have analyzed the impact of the respondents' experience and role as the confounding variables on the validity of our results, which showed marginal impact (Section V.C).

Our survey sample is not statistically random - it is a convenience sample, although we invited the respondents through various channels like personal and business contacts, interest groups, social media, and recommendations. This method provided for a fairly diverse group of experts and respondents with different experience. The experts and respondents used many agile methods such as: Scrum, Kanban, Scrumban, Extreme Programming, SAFe.
The survey was in Polish and possibly attracted most of the respondents among the peers of one of the authors (P. Gaida) working in the Tricity region of Poland, so the results it may exhibit some cultural or regional bias, which needs to be studied further. Comparison of the perception of the concept of agile mindset in Poland and other countries may bring valuable insights.

We have asked our respondents only for their (selfdeclared) experience in agile and their role in an agile team. We have not collected other data such as company size, age, industry sector or type of projects they worked on. Thus, our study provides only preliminary insight into the conceptual structure of the agile mindset.

\section{DISCUSSION}

The top 5 evaluated agile mindset elements are: "Searching for a solution to the problem instead of finding the guilty", "Being motivated", "Helping each other", "Mutual listening", and "Focus on achieving common goal". They belong only to two categories: "relationships within the team" and "individual features". This suggests that effective agile teamwork requires a specific attitude towards the team and other people as well as proactive and open mind of the individuals. This corresponds with the "growth mindset" concept from Dweck [3].

The 5 least important mindset elements in our survey are: "Asking questions in case of insufficient knowledge", "Direct communication - face to face conversations", "Equality in the team", "Team responsibility", "Maintaining a steady pace of work". They are related to organizational issues as well as shared responsibility and equality. This suggests that agile mindset is not about particular detailed practices or rituals. This is consistent with earlier findings [21, 22, 23, 24].

We have found that less experienced respondents evaluated the "Openness to others" mindset element much higher than those with more than 2 years of experience. Our working hypothesis is that it is related to learning and gathering experience at the start of the professional career. However, "openness" in general is crucial to being agile [2].

The developers considered "face to face communication" less important than the non-developers. Our working hypothesis is that they may see the meetings as (partial) waste of time that diverts them from coding. This may also indicate some overuse or misuse of meetings in the agile teams of our respondents.

We were also able to map the principles behind the Agile Manifesto [2] onto 10 evaluated elements of the agile mindset. These elements occupied positions 2, 11, 13, 14, $15,16,17,23$, and 26 (last) in our ranking ordered by the descending evaluation. This is an interesting discrepancy between what our respondents think is important to "being agile" and what the creators of the Agile Manifesto pointed out as the principles of Agile. We can hypothesize that this indicates insufficient understanding of Agile by our 
respondents, partial or flawed implementation of Agile in the respondents' teams or companies, or even a shift in practical agility from the 18 years old principles of Agile. This may also be specific to Polish IT industry and have some cultural background. Definitely, it calls for more research.

Our study is based on limited data on the respondents themselves. We have clustered the data by two levels of experience (below and above 2 years) and two types of roles (developers and non-developers). The understanding of the agile mindset may also vary by the industry sector, company size, company culture and maturity, type of projects, national and regional culture and possibly more. Our initial set of agile mindset elements may be used in such further studies.

\section{CONCLUSIONS}

We have identified 70 elements of the agile mindset from the literature and the industry experts, which answer our research question RQ1. We grouped the elements into 4 categories. Then, we have obtained and opinion-based evaluation of the importance of each agile mindset element to the effectiveness of an agile team, which answers our research question RQ2. Finally, we have analyzed and compared the evaluations to point out the most and least important elements based on the opinions of our respondents, which provides a preliminary answer to our research question RQ3. Further and more detailed study of the impact of agile mindset on the team effectiveness requires careful observation of a number of different types of projects and can be done in future research.

The detailed contribution of this paper is the identification of the elements of agile mindset as well as a preliminary evaluation of their importance to the effectiveness of an agile team based on an industrial opinion survey. This contributes to filling the gap in the literature related to the definition and scope of the agile mindset and the relative importance of its elements in the industry and education [22, 23, 24, 25].

The proposed list of agile mindset elements and their evaluations may be used as a guidance for developers, Scrum Masters and Agile coaches, where the possible applications include: (1) support for the Scrum Masters or coaches in improving the understanding of Agile by the Development Teams; (2) recommendations of improving the agile process and solving problems identified during retrospectives; (3) education and training both in the industry and academia; (4) self-development of the developers, in particular those seeking to switch to Scrum Masters or coaches. Full results of this research are available in [26]. The raw results of our survey are available in [27].

\section{ACKNOWLEDGMENT}

The authors thank all the experts and respondents who took part in the interviews and the survey.

\section{REFERENCES}

[1] Manifesto for Agile Software Development, agilemanifesto.org, 2001
[2] Principles behind the Agile Manifesto, http://agilemanifesto.org/ principles.html, 2001

[3] S. C. Dweck, Mindset: The New Psychology of Success, Random House, 2006

[4] G. Broza, The Agile Mindset - Making Agile Processes work, 3P Vantage Media, 2015

[5] A. Przybyłek, W. Kowalski, Utilizing online collaborative games to facilitate Agile Software Development, Proceedings of the 2018 Federated Conference on Computer Science and Information Systems, M. Ganzha, L. Maciaszek, M. Paprzycki (eds). ACSIS, Vol. 15, pp. 811-815, 2018, DOI: 10.15439/2018F347

[6] R. Colomo-Palacios, C. Casado-Lumbreras, P. Soto-Acosta, F. J. García-Peñalvo, E. Tovar-Caro, Competence gaps in software personnel: A multi-organizational study, Computers in Human Behavior 29 (2), pp. 456-461, 2013, DOI: 10.1016/j.chb.2012.04.021

[7] The 13th annual State of Agile Report, CollabNet VersionOne, 2019

[8] K. Schwaber, J. Sutherland, The Scrum Guide. Rules of the Game, Scrum.org, 2017

[9] M. Hammarberg, J. Sunden, Kanban in Action, Manning Publications, 2014

[10] R. Knaster, D. Leffingwell, SAFe 4.5 Distilled: Applying the Scaled Agile Framework for Lean Enterprises, 2nd Edition, Addison-Wesley Professional, 2018

[11] W. Navidi, Statistics for Engineers and Scientists, 4th Edition, McGraw-Hill Education, 2014

[12] J. A. Crowder, S. Friess, Agile Project Management: Managing for Success, Springer, 2015

[13] M. E. Moreira, The Agile Enterprise: Building and Running Agile Organizations, Apress, 2017

[14] M. E. Moreira, Being Agile, Your Roadmap to Successful Adaption of Agile, Apress, 2013

[15] C. J. Stettina, W. Heijstek, Five Agile Factors: Helping Selfmanagement to Self-reflect, A Study of Software Development Team Dynamics in SPI, R.V. O'Connor, J. Pries-Heje, and R. Messnarz (Eds.), EuroSPI 2011, CCIS 172, Springer, 2011, pp. 84-96, DOI: 10.1007/978-3-642-22206-1_8

[16] A. Stellman, J. Greene: Learning Agile: Understanding Scrum, XP, Lean and Kanban, O'Reilly Media, 2015

[17] S. McIntosh, What Exactly is the Agile Mindset?, InfoQ, 2016, https:// www.infoq.com/articles/what-agile-mindset

[18] L. Howard, What does is it mean to have an agile mindset?, Agile Connection, 2015, https://www.agileconnection.com/article/whatdoes-it-mean-have-agile-mindset

[19] S. Parvatam, It's All About the Mindset, Scrum Alliance, 2015, https:// www.scrumalliance.org/community/articles/2015/december/its-allabout-the-mindset

[20] V. Godugu, Fixed Mindset versus Agile Mindset, Scrum Alliance, 2015, https://www.scrumalliance.org/community/articles/2015/june /fixed-mindset-versus-agile-mindset

[21] L. Rich, Agile Is Not a Process, It's a Mindset, Agile Connection, 2018, https://www.agileconnection.com/article/agile-not-process-it-smindset

[22] F. Zieris, S. Salinger, Doing scrum rather than being Agile: A case study on actual nearshoring practices, IEEE 8th International Conference on Global Software Engineering, pp. 144-153, 2013, DOI: 10.1109/ICGSE.2013.26

[23] H. van Manen, H. van Vliet, Organization-Wide Agile Expansion Requires an Organization-Wide Agile Mindset, A. Jedlitschka et al. (Eds.): PROFES 2014, LNCS 8892, Springer, pp. 48-62, 2014

[24] A. Martin, C. Anslow, D. Johnson, Teaching Agile Methods to Software Engineering Professionals: 10Years, 1000 Release Plans, H. Baumeister et al. (Eds.): XP 2017, LNBIP 283, Springer, pp. 151-166, 2017, DOI: $10.1007 / 978-3-319-57633-6 \_10$

[25] G. C. Gannod, W. F. Eberle, D. A. Talbert, R. A. Cooke, K. Hagler, K. Opp, J. Baniya, Establishing an agile mindset and culture for workforce preparedness: A baseline study, Proceedings - Frontiers in Education Conference, 2019, DOI:10.1109/FIE.2018.8658712

[26] P. Gaida, Analysis of the agile mindset for software projects, MSc Thesis, supervisor J. Miler, Gdansk University of Technology, Poland, 2018 (in Polish)

[27] J. Miler, P. Gaida, Survey on agile mindset and agile team effectiveness, data.mendeley.com, DOI: 10.17632/phvx6nts6b.1 